\title{
Chinese University Students' Perceptions of Teacher Code-switching in EFL Speaking Classrooms
}

\author{
Yuehan Luo ${ }^{1}$ \\ ${ }^{1}$ Department of English, the Hong Kong Polytechnic University, HKSAR, China \\ Correspondence: Yuehan Luo, Department of English, the Hong Kong Polytechnic University, HKSAR, China.
}

Received: September 19, 2019

Accepted: October 29, 2019 Online Published: October 31, 2019

doi: $10.5539 /$ elt.v12n11p119

URL: https://doi.org/10.5539/elt.v12n11p119

\begin{abstract}
While research on students' perceptions of code-switching in EFL classrooms has proliferated over the past several decades, limited research has been conducted to understand students' perceptions with different levels of language proficiency in English. Drawing on both quantitative and qualitative data collected from students with different English proficiency levels, the present research reports students' perceptions of teacher code-switching in EFL speaking classrooms in Chinese tertiary context. The quantitative data collected from questionnaires show that students do not favor total immersion. Students believe that English should be the medium of instruction for activities and their opinions show mixed results under the circumstances of teaching grammar and usage of English. Mixed opinions are also found in terms of teacher switching to Chinese to give administrative information and test information. The qualitative data in the questionnaire suggest that students prefer Chinese teacher of English owning to better understanding, and they attribute their levels of English as the deciding factor of their preferences. No statistical differences achieved regarding the perceptions from Level One and Level Two students. Findings suggest that the systematic and effective use of learner's L1 is beneficial for language teaching in speaking classrooms, and L1 can be regarded as a powerful tool to develop effective teaching approaches for English language teachers.
\end{abstract}

Keywords: code-switching, student perceptions, EFL speaking classrooms

\section{Introduction}

After the enactment of Bilingual Education Act (BEA) in the 1960s, code-switching, the phenomenon of alternating from one language to another in the same discourse, was introduced for the first time to second language classrooms in the United States (Nunan \& Carter, 2001). Since then, the field of second language education has witnessed debates in terms of whether mother language should be covered in foreign language classrooms. Some researchers were significantly affected by Krashen's (1988) comprehensible input theory, and they believed that total immersion is beneficial for language learning (Chambers, 1991; Krashen \& Terrell, 1988). Other scholars assumed that L1 should not be eliminated from language classrooms and introduced the systematic way of adopting L1 to facilitate language learning (Atkinson, 1989; Cook, 1991; Ellis, 1984; Macaro, 1997).

In universities in China, parents and administrators have reached an agreement that Chinese should not be used in English language classrooms and such agreement seems to become a tacit policy, especially in listening and speaking classrooms. The teacher would be blamed for using mother language as it might result in students' lack of exposure to the target language, thereby causing deficiencies in language learning. Nevertheless, the problem of whether teachers should use students' first language is neglected in the new syllabus of college English issued by the Ministry of Education, perhaps due to the controversies of this issue (Guo, 2007).

Previous studies focusing on student perceptions pay most attention to students' general impressions of code-switching while neglecting their language proficiency (Guo, 2007; Meji \& Zhao, 2010; Tian \& Hennebry, 2016). Although these studies provide valuable foundation for understanding student perceptions of teacher code-switching, these studies do not touch upon the mediating role of learners' L2 proficiency. The present study sets out to further contribute to the debate regarding whether mother language should be included in foreign language classrooms by focusing on the perceptions of learners with different L2 proficiency levels. In this way, it can achieve a better understanding of teacher code-switching in English speaking classrooms in the Chinese context, thereby bringing practical implications for language teachers and policy makers. A study of this nature 
can also shed light on policy making regarding teachers' use of students' first language at tertiary level.

\section{Literature Review}

There is evidence that teachers would use learners' L1 regardless of the educational contexts and national guidelines (Levine, 2003), but the extent of L1 use varies greatly. For instance, this extent is around $60 \%$ in New Zealand secondary schools (Kim \& Elder, 2005), while 90\% in one university in the United States (Duff \& Polio, 1990). Teachers employed learners' L1 mainly to explain new vocabulary and grammar items (Kim \& Elder, 2005), to manage classroom behaviours (Macaro, 2001), and to develop a positive teacher-student relationship (Duff \& Polio, 1990).

Previous studies have examined students' preferences towards teacher code-switching. For instance, Duff and Polio (1990) found that students were satisfied with teachers' language choices even the use of L1 ranged from $0 \%$ to $90 \%$. In a similar way, Macaro (1997) examined L2 exclusivity and adult learners' attitudes, finding that students have either reported being demotivated while confronted with L2 exclusivity, or just "go along with it" (p.127). Levine (2003) investigated the attitudes of both students and teachers, focusing on learner anxiety while facing target language use. The study reported that although some students felt anxious when being exposed to the target language, it would be useful to employ the target language in teaching rather than to fall back on students' first language. The findings of these studies seemed to be mixed and students assumed that the quantity of teacher's L1 use did not play a decisive role in their satisfaction, but the effectiveness of L1 use.

Individual difference factors have been reported to exert an influence on students' perceptions, such as gender-caused differences and age-caused differences. With regard to gender-caused differences, research implied that male students are less likely to have the exclusive use of the target language than female students (Stable \& Wikeley,1999; Jones et al., 2001). However, there is some other research suggesting that female students reported the same problem with L2 exclusivity (Clark \& Trafford, 1994). As for age differences, Macaro and Lee (2013) examined Korean learners' perceptions of teacher code-switching and they found that age was an influencing factor of students' perception. Younger learners have reported that they preferred teacher code-switch to teach vocabularies.

Learners' attitudes towards the use of the first language varied across teaching contexts (Kern, 1995; Rolin-Ianziti \& Varshney, 2008). In the Chinese context, the existing research suggests that learners do not want L1 to be totally excluded (Guo, 2007; Meji \& Zhao, 2010). Using the semi-structured interviews, Guo (2007) investigated students' response to teachers' code choices, finding that they response positively to code-switching. Similarly, Meji and Zhao (2010) examined perceptions of English major students in one university and students assumed that the first language played a 'functional' role in English language classrooms. More recent studies explored focused on nuanced perspectives of code-switching. To be specific, Tian and Hennebry (2016) examined students' preferences towards vocabulary teaching with either English only or Chinese only explanations. Interestingly, the results unveiled that students welcomed a 'bilingual' approach to teach new vocabularies, thereby strengthening learning outcomes. Even if the above-reviewed research seemed to reveal positive reactions from students in terms of code-switching, most of their perceptions were general, without taking into account various types of foreign language classrooms and none of them has investigated the perceptions of students with different levels of English proficiency. Clearly, such ambiguity calls for more research in different contexts with different levels of learner proficiency as a key factor.

In reviewing the previous research, two research gaps have been identified: (1) Even though research has been conducted on code-switching and students' perceptions, most of them pay attention to general impression towards teacher's code-choice, which makes general implications be elicited. Hence, it is vital to examine specific contexts where L1 might be used, for example, in English phonetics, listening and speaking classrooms; (2) more research is needed to investigate learner proficiency as an important factor in deciding their perceptions. To understand students' opinions is of great significance as it pedagogically informs and empowers second language teachers. Realising these research gaps, the present study proposes the following research questions.

1) What are students' attitudes towards teacher code-switching in English speaking classes?

2) Do students prefer 'immersion mode' or switching to Chinese in English speaking classes?

3) Are there any differences in perceptions between students with different levels of language proficiency in English speaking classes?

\section{Methodology}

The present study works under a realist epistemological foundation with a relatively fixed design (Cohen, 2007; Robson, 2011). A mixed-method approach was utilized to address the research questions and the overall strategy 
was to survey two groups of students with different language proficiency using the same student questionnaire. In the questionnaire, both close-ended questions with the 4-point Likert scale and several opened-ended questions were employed to elicit students' perceptions. To make up for the drawbacks of purely quantitative data, the study incorporates qualitative elements to elicit qualitative data as quantitative data is easier to generalise patterns while qualitative data can bring about some in-depth understanding (Creswell, 2003).

\subsection{Context and Participants}

As the present research aims to investigate Chinese learners' perceptions of teacher code-switching at the tertiary level, there is a necessity to briefly review the background of English language teaching in Chinese universities. Based on the National English Language Teaching Guidance (NELTG) issued by the Ministry of Education, English is a compulsory subject in universities of China (Zhang, 2012). There are two categories of learners of English, that is, non-English majors (NEM) and English-majors (EM). For NEMs, they are grouped into Level One and Level Two, based on the test scores in college entrance examinations. Students scored 120 and above belong to Level One while students scored below 120 are categorized into Level Two. Such stratification makes the Chinese university context a useful one to examine students' perceptions of teacher codes witching with different levels of language proficiency.

Participants were first-year NEMs from two natural classes which were taught by the same Chinese English teacher. One class of students $(\mathrm{N}=30)$ majored in physical education, while the other $(\mathrm{N}=40)$ majored in Chinese literature. The finalised questionnaires were administered to these two cohorts of students after they accomplished a 45-minute English speaking class. Altogether, 25 Level-one students finished their pencil-paper questionnaires with a valid response rate of $83 \%$ ad 39 Level-two students completed the survey with a valid response rate of $97 \%$.

\subsection{Instrument}

The present study drew on the questionnaire developed by Levine (2003) and contextualised some of the questionnaire items. The seminal work of Levine (2003) investigated attitudes and factors associated with learner anxiety under the circumstance of teacher code switching while the present study intends to investigate students' preferences towards code-switching in English-speaking classes. Levine's (2003) questionnaire was modified by employing some of the items and by adding new items, especially to answer the second research question. Prior to the survey, questionnaire items were piloted on students with similar backgrounds as the participants of this study.

A semi-structured questionnaire was developed. Starting with background information of the participants, including age, gender and years of learning English, six statements were covered in the questionnaire. (Statement example: "I believe that there are no situations in which the first language should be used in the classroom"). In the meantime, the 4-point Likert scale, ranging from strongly agree to strongly disagree, was provided after each statement in with a view to eliciting participants' levels of the agreement relating to their attitude and belief (Punch, 2005).Also, students were given enough space to write down specific reasons for choosing the options and commenting on this statement. The questionnaire was provided in Chinese, participants' first language in order to reduce confusion.

\subsection{Data Collection and Analysis}

Prior to data collection, informed written consent was obtained from all the student participants. Consent forms were handed out together with student questionnaires. Students were fully informed that their participation was anonymous and there would be no subsequent discrimination in scores. The final version of the student questionnaire was administered to two cohorts of students at the end of two oral English sessions separately and the participants were given approximately 15 minutes to accomplish the paper-pencil copies.

The data analysis consisted of two sections. Students' response to the four-point Likert scale were keyed into Excel and imported to SPSS version 22 for statistical analysis. The descriptive profile for these two levels of students indicated that the data was non-parametric. As a consequence, the Mann-Whitney U test was employed to compare means of these two cohorts of students, and to examine their attitudes towards the six statements presented in the questionnaire (Field, 2000). The qualitative data was generated from the six open-ended questions after the six statements. 64 participants have numbered anonymously from S1 to S64. S1-S25 were level one students, while S26-S64 belong to level two students.

\section{Findings}

Statement 1: I believe that there are no situations in which the first language (i.e, Chinese) should be used in the classroom (total immersion in FL is best). 
With regard to students' preference towards English-only instruction or instruction which contains some switching to Chinese (preference towards "total immersion"), most of the students held quite negative views towards 'total immersion'. Among all the participants, over $73 \%$ of them disagreed or strongly disagreed with this statement. In the meantime, according to the Mann-Whitney $U$ test, the means of their responses between Level One students and Level Two students did not reach statistical significance $(\mathrm{p}>0.05)$. Even though Level One students disagreed to a larger extent $(\mathrm{M}=3.00)$ than Level Two students did $(\mathrm{M}=2.64)$, this difference still did not reach statistical significance $(\mathrm{p}>0.05)$. Hence, students of these two proficiency levels share similar opinions.

As pointed out by one student (S23): "We cannot understand it when the teacher speaks English for the entire lesson." And this theme re-emerged in their comments. Another student (S49) commented: "English classrooms are where we are supposed to learn new knowledge. If we cannot understand what the teacher is saying, then some of us will not listen carefully or even drift away from the class". There were some quite thoughtful remarks proposed by one student: "Teachers sometimes only pay attention to those classmates whose oral English is fairly good. In this case, the lower-achievers gradually lose their interests" (S40).

Table 1. Questionnaire results: level one students $(\mathrm{n}=25)$

\begin{tabular}{|c|c|c|c|c|c|}
\hline $\begin{array}{c}\text { No } \\
.\end{array}$ & Statement & $\begin{array}{c}\text { Strongly } \\
\text { Agree }\end{array}$ & Agree & Disagree & $\begin{array}{c}\text { Strongly } \\
\text { Disagree }\end{array}$ \\
\hline 1 & $\begin{array}{l}\text { I believe that there are no situations in which } \\
\text { the first language (i.e, Chinese) should be } \\
\text { used in the classroom (total immersion in FL } \\
\text { classes is best). }\end{array}$ & $\begin{array}{c}1 \\
(4 \%)\end{array}$ & $\begin{array}{c}4 \\
(16 \%)\end{array}$ & $\begin{array}{c}14 \\
(56 \%)\end{array}$ & $\begin{array}{c}6 \\
(24 \%)\end{array}$ \\
\hline 2 & $\begin{array}{l}\text { I believe that lecturer should use only } \\
\text { English to teach us grammar or usage of } \\
\text { English. }\end{array}$ & $\begin{array}{c}2 \\
(8 \%)\end{array}$ & $\begin{array}{c}11 \\
(44 \%)\end{array}$ & $\begin{array}{c}11 \\
(44 \%)\end{array}$ & $\begin{array}{c}1 \\
(4 \%)\end{array}$ \\
\hline 3 & $\begin{array}{l}\text { I believe that lecturer should use only } \\
\text { English when giving directions for classroom } \\
\text { activities. }\end{array}$ & $\begin{array}{c}2 \\
(8 \%)\end{array}$ & $\begin{array}{c}17 \\
(68 \%)\end{array}$ & $\begin{array}{c}5 \\
(20 \%)\end{array}$ & $\begin{array}{c}1 \\
(4 \%)\end{array}$ \\
\hline 4 & $\begin{array}{l}\text { I believe that the lecturer should use only } \\
\text { English to discuss course policies, } \\
\text { attendance, and other information related to } \\
\text { exams. }\end{array}$ & $\begin{array}{c}1 \\
(4 \%)\end{array}$ & $\begin{array}{c}8 \\
(32 \%)\end{array}$ & $\begin{array}{c}14 \\
(56 \%)\end{array}$ & $\begin{array}{c}2 \\
(8 \%)\end{array}$ \\
\hline 5 & $\begin{array}{l}\text { If I can choose, I prefer oral English to be } \\
\text { taught by a foreign teacher whose native } \\
\text { language is English and cannot communicate } \\
\text { in Chinese. }\end{array}$ & $\begin{array}{c}3 \\
(12 \%)\end{array}$ & $\begin{array}{c}7 \\
(28 \%)\end{array}$ & $\begin{array}{c}13 \\
(52 \%)\end{array}$ & $\begin{array}{c}2 \\
(8 \%)\end{array}$ \\
\hline 6 & $\begin{array}{l}\text { If I can choose, I prefer oral English to be } \\
\text { taught by teacher in China who can use some } \\
\text { Chinese in class to help me understand. }\end{array}$ & $\begin{array}{c}8 \\
(32 \%)\end{array}$ & $\begin{array}{c}13 \\
(52 \%)\end{array}$ & $\begin{array}{c}3 \\
(12 \%)\end{array}$ & $\begin{array}{c}1 \\
(4 \%)\end{array}$ \\
\hline
\end{tabular}

Statement 2: I believe that lecturer should use only English to teach us grammar or usage of English.

As shown in Table 1 and Table 2, disparities can be found from these two groups of students regarding their attitudes towards whether the teacher should use English to teach grammar or language use. Among all the participants surveyed, $51 \%$ of them disagreed or strongly disagreed with this statement, while $49 \%$ of them agreed or strongly agreed with it. Furthermore, the Mann-Whitney $U$ test implied that no significant differences exist between these two groups of students $(p>0.05)$. Hence, one can see that basically, students from both groups shared their opinions in terms of this statement.

As commented by one respondent: "The teacher can train our way of thinking in English rather than letting us fall back on the Chinese way of thinking when we have English input for grammar" (S50). Some other comments showed an opposite view against this statement. For instance, S67 wrote that "Grammar is the most difficult part to learn, so Chinese should be provided to give us a better idea". 
Table 2. Questionnaire results: level two students $(\mathrm{n}=39)$

\begin{tabular}{|c|c|c|c|c|c|}
\hline No. & Statement & Strongly Agree & Agree & Disagree & $\begin{array}{r}\text { Strongly } \\
\text { Disagree }\end{array}$ \\
\hline 1 & $\begin{array}{l}\text { I believe that there are no situations in } \\
\text { which the first language (i.e, Chinese) } \\
\text { should be used in the classroom (total } \\
\text { immersion in FL classes is best). }\end{array}$ & $\begin{array}{c}4 \\
(10 \%)\end{array}$ & $\begin{array}{c}8 \\
(21 \%)\end{array}$ & $\begin{array}{c}25 \\
(64 \%)\end{array}$ & $\begin{array}{c}2 \\
(5 \%)\end{array}$ \\
\hline 2 & $\begin{array}{l}\text { I believe that lecturer should use only } \\
\text { English to teach us grammar or usage of } \\
\text { English. }\end{array}$ & $\begin{array}{c}3 \\
(8 \%)\end{array}$ & $\begin{array}{c}15 \\
(38 \%)\end{array}$ & $\begin{array}{c}20 \\
(51 \%)\end{array}$ & $\begin{array}{c}1 \\
(3 \%)\end{array}$ \\
\hline 3 & $\begin{array}{l}\text { I believe that lecturer should use only } \\
\text { English when giving directions for } \\
\text { classroom activities. }\end{array}$ & $\begin{array}{c}5 \\
(13 \%)\end{array}$ & $\begin{array}{c}25 \\
(64 \%)\end{array}$ & $\begin{array}{c}9 \\
(23 \%)\end{array}$ & $\begin{array}{c}0 \\
(0 \%)\end{array}$ \\
\hline 4 & $\begin{array}{l}\text { I believe that the lecturer should use only } \\
\text { English to discuss course policies, } \\
\text { attendance, and other information related } \\
\text { to exams. }\end{array}$ & $\begin{array}{c}5 \\
(13 \%)\end{array}$ & $\begin{array}{c}17 \\
(44 \%)\end{array}$ & $\begin{array}{c}17 \\
(44 \%)\end{array}$ & $\begin{array}{c}0 \\
(0 \%)\end{array}$ \\
\hline 5 & $\begin{array}{l}\text { If I can choose, I prefer oral English to be } \\
\text { taught by a foreign teacher whose native } \\
\text { language is English and cannot } \\
\text { communicate in Chinese. }\end{array}$ & $\begin{array}{c}4 \\
(4 \%)\end{array}$ & $\begin{array}{c}11 \\
(28 \%)\end{array}$ & $\begin{array}{c}21 \\
(54 \%)\end{array}$ & $\begin{array}{c}3 \\
(8 \%)\end{array}$ \\
\hline 6 & $\begin{array}{l}\text { If I can choose, I prefer oral English to be } \\
\text { taught by teacher in China who can use } \\
\text { some Chinese in class to help me } \\
\text { understand. }\end{array}$ & $\begin{array}{c}7 \\
(20 \%)\end{array}$ & $\begin{array}{c}26 \\
(67 \%)\end{array}$ & $\begin{array}{c}6 \\
(15 \%)\end{array}$ & $\begin{array}{c}0 \\
(0 \%)\end{array}$ \\
\hline
\end{tabular}

Statement 3: I believe that the lecturer should use only English when giving directions for classroom activities.

According to Table 1 and Table 2, the participants have revealed a relatively positive attitude towards teachers using English to give directions for classroom activities. $76 \%$ of the student participants agreed or strongly agreed with this statement. In the meantime, no significant differences have been found between two groups' means $(p>0.05)$ based on the results of the Mann-Whitney $U$ test. It seemed that both groups of students agreed that English should be the medium of instruction for classroom activities. One student pointed out that "It is a very good chance for us to practice English" (S2). "As it is English speaking class, activities should be conducted in order to give us more taste of English- speaking classrooms" (S61). Another student gave out the reason for the option: "Usually the teacher repeats herself a lot when giving us directions, so most of us are quite familiar with her directions in English, so it will not be a big problem for us" (S17).

Statement 4: I believe that the lecturer should use only English to discuss course policies, attendance, and other information related to exams.

As presented in Table 1 and Table 2, 52\% of the students surveyed response negatively (disagreed or strongly disagreed) while $48 \%$ of them agreed or strongly agreed with the statement. This reveals that students' opinions were mixed as well regarding this statement. Also, no significant difference $(p>0.05)$ has been shown according to the results of the Mann-Whitney U test, which seemed to suggest that students from two levels hold similar opinions towards teacher code-switching in terms of these aspects.

A closer look at the qualitative comments revealed more details. "Very often, the teacher uses English to talk about course policies, and checks attendances because it has already become classroom routines, so most of us can understand" (S33). Another student pointed out the negative consequence of using English to explain information correlated with exams. "Assessment is very important to us all, and we do not want to leave any information behind. Thus, Chinese is an easy way for as to understand" (S54). This opinion is also supported by S27, S51, and S70. According to their feedback, it appeared that students would treat Chinese as a 'shortcut' to exams. As commented by one respondent: "Chinese is direct and clear than English when teacher inform us about the final exam" (S70). 
Table 3. Comparing class means: Results of Mann-Whitney U tests

\begin{tabular}{|c|c|c|c|c|c|c|}
\hline No. & Statement & $\begin{array}{c}\text { Whole } \\
\text { Sample } \\
\text { Mean }(n=64)\end{array}$ & $\begin{array}{l}\text { Class } \\
\text { one } \\
\text { Mean }(\mathrm{n} \\
=25)\end{array}$ & $\begin{array}{l}\text { Class } \\
\text { Two } \\
\text { Mean(n } \\
=39)\end{array}$ & $\begin{array}{l}\text { Mann-Whi } \\
\text { tney U } \\
\text { Value }\end{array}$ & $\begin{array}{c}\text { Sig } \\
\text { Level }\end{array}$ \\
\hline 1 & $\begin{array}{l}\text { I believe that there are no situations } \\
\text { in which the first language (i.e, } \\
\text { Chinese) should be used in the } \\
\text { classroom (total immersion in FL } \\
\text { classes is best). }\end{array}$ & 2.78 & 3.00 & 2.64 & 370 & 0.064 \\
\hline 2 & $\begin{array}{l}\text { I believe that lecturer should use } \\
\text { only English to teach us grammar or } \\
\text { usage of English. }\end{array}$ & 2.47 & 2.44 & 2.49 & 465 & 0.732 \\
\hline 3 & $\begin{array}{l}\text { I believe that lecturer should use } \\
\text { only English when giving directions } \\
\text { for classroom activities. }\end{array}$ & 2.14 & 2.20 & 2.10 & 461 & 0.664 \\
\hline 4 & $\begin{array}{l}\text { I believe that the lecturer should use } \\
\text { only English to discuss course } \\
\text { policies, attendance, and other } \\
\text { information related to exams. }\end{array}$ & 2.45 & 2.68 & 2.31 & 359 & 0.053 \\
\hline 5 & $\begin{array}{l}\text { If I can choose, I prefer oral English } \\
\text { to be taught by a foreign teacher } \\
\text { whose native language is English } \\
\text { and cannot communicate in Chinese. }\end{array}$ & 2.56 & 2.52 & 2.59 & 467 & 0.754 \\
\hline 6 & $\begin{array}{l}\text { If I can choose, I prefer oral English } \\
\text { to be taught by teacher in China who } \\
\text { can use some Chinese in class to } \\
\text { help me understand. }\end{array}$ & 1.94 & 1.89 & 1.97 & 435 & 0.407 \\
\hline
\end{tabular}

Statement 5: If I can choose, I prefer oral English to be taught by a foreign teacher whose native language is English and cannot communicate in Chinese.

As shown in Tables 1 and 2, 61\% of the students surveyed disagreed or strongly disagreed with this item while $39 \%$ of them responded to this statement favourably. In Tables 3, no significant difference $(p>0.05)$ between these two groups of students has been found in view of the Mann-Whitney U test results. Hence, it can be seen that students from two proficiency levels have similar opinions towards this statement.

Students have provided various reasons for their preferences. Students preferring the lesson to be taught by a Chinese teacher of English commented: "If the teacher cannot speak Chinese at all, then most of us will not be able to understand at some point" (S4); "It might hinder the communications between teacher and student" (S68); "If we do not understand the teacher, then the whole lesson would be ineffective" (S8). Students who were in favour of a foreign teacher held such opinions: "Foreign teachers can bring more authentic oral English compared to Chinese teachers" (S9); "It is interesting and fun to have a foreign teacher as we already have so many Chinese teachers" (S29). One Student gave some more balanced comments: "if a Chinese teacher works with a foreign teacher, then oral English will be more interesting and effective" (S31).

Statement 6: If I can choose, I prefer oral English to be taught by teacher in China who can use some Chinese in classes to help me understand.

As a comparative item to item 5, statement 6 examined students' attitudes towards oral English teaching by a Chinese teacher. Interestingly, as revealed in Table 1 and Table 2, a predominantly $84 \%$ of all the students surveyed disagreed or strongly disagrees with this statement. In the meantime, only $17 \%$ of the students surveyed disagreed or strongly disagreed with item 6 . Also, as can be seen in Tables 3 , no statistical differences 
were found between two group means $(p>0.05)$. In this case, it a conclusion can be drawn that both groups of participants preferred the lesson to be taught by a Chinese teacher of English.

Students' comments centered around "better communication" and "better teaching technics" of Chinese teachers of English. For instance, one student commented: "I feel more psychologically close to Chinese teachers" (S17); "We can learn some experience from Chinese teacher of English." (S29) and "Culturally difficult to understand foreigners" (S6). Some students, nevertheless, questioned the "professionalism in terms of oral English language teaching" (S51) and were concerned about "Chinglish" problem from Chinese teachers (S56). Again, students regarded their proficiency level as a quite crucial factor contributing to their preferences. "My level of English would make it difficult for me to understand a foreign teacher, so I prefer a Chinese teacher to teach us oral English" (S7).

\section{Discussions and Implications}

In this part of the paper, answers to the three research questions are provided and the implications of this study are proposed.

RQ1: What are students' attitudes towards teacher code-switching in English speaking class?

Overall, both categories of students did not favour L2 exclusivity. Most participants disagreed (73\%) that Chinese should be excluded from the oral English classroom. This is in accordance with the findings of Guo (2007) that students have also reported positive views towards teacher code-switching regarding clarifying meaning and building confidence. A majority of the student respondents held the view that English should be the medium of instruction for classroom activities. Students' opinions showed mixed results under the circumstance of teaching grammar and usage of English. In terms of teacher switching to Chinese to give administrative information and test information, mixed opinions were found as well.

RQ2: Do students prefer "immersion mode" or switching to Chinese to facilitate understanding in English speaking class?

Relevant to students' preference towards 'immersion mode' or 'switching to Chinese' were their opinions towards nonnative-English-speaking teachers (NNESTs) and native-English-speaking teachers (NESTs) (Statement 5 and Statement 6). As predominantly $84 \%$ of the respondents reported their preferences on Chinese teachers of English, it implied that they preferred NESTs slightly over NNESTs. This preference was also echoed in the earlier studies on students' preference for these two kinds of teachers (Cheung, 2007; Moussu, 2008; cited in Macaro \& Lee, 2013). These studies have provided some evidence that students hold positive opinions towards NNESTs. They also gave some favourable comments that encourage the combination of teaching by both NESTS and NNESTs in a way that facilitates speaking English.

RQ 3: Are there any significant statistical differences in students' attitudes at different English proficiency levels in English speaking class?

It is clear in Table 3 that Level One students disagreed to a larger extent than $(\mathrm{M}=2.68)$ those of Level Two (M $=2.31)$ for statement 4 . In spite of this, their difference did not reach statistical differences $(P>0.05)$. Hence, it can be deferred that of all the six statements investigated, there were no statistical differences achieved regarding the perceptions from these two types of students. A possible reason is identified as follows. According to the feedback of the course lecturer, even though Level Two students scored higher in College Examination (English subject scored above 120) than Level One students (English subject scored below 120), there was no sharp contrast between their English proficiency levels. This merits further research when students' English proficiency level varies considerably.

From the discussion before, one can see that L1 has its role to play in English language classrooms and students do not want L1 to be totally excluded from oral English classrooms. This echoes Stern's (1992, p.282) observation that L1 and L2 connection is an "indisputable fact of life". Therefore, it highlights the importance to take into account how to use L1 systematically and effectively in language classrooms. L1 can be used as a powerful tool to develop effective teaching approaches and methods. For instance, some scholars (Tian \& Hennebry, 2016) went further to explore the bilingual teaching approach, either by NNESTS or with NNESTS and NESTs combined, especially for vocabulary teaching. Specifically, as indicated in the qualitative findings, some students regard teacher code-switching as a short-cut to exams. In other words, teachers would switch to Chinese to cover all the learning materials to help students to prepare exams, which was argued by Macaro (2015) as the negative washback of the exams. If this is the case, then further research is needed to support what systematic and principled use of L1 would be. Moreover, the status of bilingual teachers should be raised since they can operate as bilingual dictionaries as opposed to monolingual teachers. Unfortunately, at the national 
educational level, the doctrine of L2 exclusivity is still well received by parents and administrators. Evidently, this assumption is not based on empirical research.

\section{Conclusion}

Findings from this research suggest imply that students do not want Chinese to be fully excluded from the oral English-speaking class. Since this was the case both for English Level-One and English Level-two, it would seem to suggest that total immersion is not well-suited to these two levels of students. Moreover, students prefer NESTs in oral English-speaking class considering better understanding and classroom interaction. An analysis of students' qualitative response seems to reveal that one of the deciding factors affecting students' decision making is their present English proficiency level, which is the primary concern for not welcoming total immersion and NNESTs.

The present study is not without its limitations. On the one hand, sample sizes can be enlarged to facilitate better understanding. On the other hand, a first glance over students' comments reveals that even though enough spaces have been left for their comments, most of these comments were just one or two sentences. Further research should be conducted with wider sample sizes and more in-depth interview data to generate a more fined grained understanding. Apart from this, as aforementioned, it might be helpful to examine learner preferences on teachers' code choices with learner proficiency in sharp contrast.

\section{References}

Atkinson, D. (1987). The mother tongue in the classroom: A neglected resource? ELT Journal, 41(4), 241-247. https://doi.org/10.1093/elt/41.4.241

Chambers, F. (1991). Promoting use of the target language in the classroom. The Language Learning Journal, 4(1), 27-31. https://doi.org/10.1080/09571739185200411

Clark, A., \& Trafford, J. (1996). Return to gender: Boys' and girls' attitudes and achievements. Language Learning Journal, 14, 40. https://doi.org/10.1080/09571739685200371

Cohen, L., Manion, L., \& Morrison, K. (2007). Research methods in education (6th ed.). London; New York: Routledge. https://doi.org/10.4324/9780203029053

Cook, V. (1991). Second language learning and language teaching. London: Edward Arnold.

Cook, G. (2010). Translation in language teaching: An argument for reassessment. Oxford, England: Oxford University Press. https://doi.org/10.1017/S0261444809990140

Creswell, J. (2009). Research design: Qualitative, quantitative, and mixed methods approaches (3rd ed.). Thousand Oaks, Calif.: Sage Publications.

Duff, P., \& Polio, C. (1990). How much foreign language is there in the foreign language classroom? Modern Language Journal, 74(2), 154-166. https://doi.org/10.1111/j.1540-4781.1990.tb02561.x

Ellis, R. (1984) Classroom Second Language Development Oxford and New York: Pergamon Institute of English.

Field, A. (2000). Discovering statistics using SPSS for windows: Advanced techniques for the beginner. London: Sage publications Ltd.

Guo, T. (2007). A case study of teacher's codeswitching behaviors in mainland China's university EFL classrooms and students' reactions to the codeswitching. Doctoral dissertation, University of Oxford, England.

Kern, R. (1995). Students' and teachers' beliefs about language learning. Foreign Language Annals, 28(1), 71-92. https://doi.org/10.1111/j.1944-9720.1995.tb00770.x

Kim, S. H. O., \& Elder, C. (2005). Language choices and pedagogic functions in the foreign language classroom: A cross-linguistic functional analysis of teacher talk. Language Teaching Research, 9(4), 355-380. https://doi.org/10.1191/13621688051r173oa

Krashen, S. D. (1985). The input Hypothesis: Issues and implications. New York: Longman.

Levine, Glenn S. (2003). Student and instructor beliefs and attitudes about target language ese, first language use, and anxiety: Report of a questionnaire study. Modern Language Journal, 87(3), 343-64. https://doi.org/10.1111/1540-4781.00194

Ling, C., \& Braine, G. (2007). The attitudes of university students towards non-native speakers English teachers in Hong Kong. RELC Journal, 38(3), 257-277. https://doi.org/10.1177/0033688207085847 
Moussu, L., \& Llurda, E. (2008). Non-native English-speaking English language teachers: History and research. Language Teaching, 41(3), 315-348. https://doi.org/10.1017/S0261444808005028

Macaro, E. (1997) Target language, collaborative learning and autonomy. Clevedon, UK: Multilingual Matters.

Macaro, E., \& Lee, J. H. (2013). Teacher language background, codeswitching, and English-only instruction: Does age make a difference to learners' attitudes? TESOL Quarterly, 47(4), 717-742. https://doi.org/ $10.1002 /$ tesq. 74

Nunan, D., \& Carter, R. (Eds.). (2001). The Cambridge guide to teaching English to speakers of other languages. Ernst Klett Sprachen.

Punch, K. (2005). Introduction to social research: Quantitative and qualitative approaches (2nd ed.). London, Thousand Oaks, Calif.: SAGE.

Robson, C. (2011). Real world research: A resource for users of social research methods in applied settings (3rd ed.). Chichester, West Sussex: Wiley.

Rolin-Ianziti, J., \& Varshney, R. (2009). Students' views regarding the use of the first language: An exploratory study in a tertiary context maximizing target language use. The Canadian Modern Language Review / La Revue Canadienne Des Langues Vivantes, 65(2), 249-273. https://doi.org/10.3138/cmlr.65.2.249

Stables, A., \& Wikeley, F. (1999). From bad to worse? Pupils' attitudes to modern foreign languages at ages 14 and 15. Language Learning Journal, 20(1), 27-31. https://doi.org/10.1080/09571739985200231

Tian, \& Hennebry. (2016). Chinese learners' perceptions towards teachers' language use in lexical explanations: A comparison between Chinese-only and English-only instructions. System, 63, 77-88. https://doi.org/10.1016/j.system.2016.08.005

Van Der Meij, H., \& Zhao, X. (2010). Codeswitching in English courses in Chinese universities. The Modern Language Journal, 94(3), 396-411. https://doi.org/10.1111/j.1540-4781.2010.01090.x

Zhang, W. (2012). A Brief Introduction to Foreign Languages Education Policy in China. Online Submission.

\section{Copyrights}

Copyright for this article is retained by the author(s), with first publication rights granted to the journal.

This is an open-access article distributed under the terms and conditions of the Creative Commons Attribution license (http://creativecommons.org/licenses/by/4.0/). 